Research Article

Open Access

\title{
The Role of LTST Hot Water immersion on Quality of Peach Fruit during Storage
}

\author{
Sadiq Khan 1 , Irfan Ullah ${ }^{1}$, Nadeem Khan ${ }^{2}$, Amjad Iqbal2,3*, Tariq Shah ${ }^{4}$, Farooq Shah ${ }^{2}$, Badshah Islam ${ }^{2}$, Arshad \\ Ali $^{2}$ and Rashad Waseem Khan Qadri ${ }^{3,5}$ \\ IDepartment of Horticulture, The University of Agriculture Peshawar, Pakistan \\ 2Department of Agriculture, Abdul Wali Khan University, Mardan, Pakistan \\ ${ }^{3}$ Coconut Research Institute, Chinese Academy of Tropical Agricultural Sciences, Wenchang City, 571339, Hainan, China \\ ${ }^{4}$ College of Economics and Land Management, Huazhong Agricultural University, Wuhan, Hubei 430070, China \\ Institute of Horticulture, University of Agriculture Faisalabad, Pakistan
}

\section{Article Info}

*Corresponding author:
Amjad Iqbal
Coconut Research Institute
Chinese Academy of Tropical Agricultural
Sciences
Wenchang City
571339, Hainan
China
E-mail: amjadiqbal147@gmail.com

Received: September 1, 2016 Accepted: September 7, 2016

Published: December 21, 2016

Citation: Khan S, Ullah I, Khan N, et al. The Role of LTST Hot Water immersion on Quality of Peach Fruit during Storage. Madridge J Food Technol. 2016; 1(1): 31-36. doi: 10.18689/mjft-1000105

\section{Copyright: @ 2016 The Author(s). This work is licensed under a Creative Commons Attribution 4.0 International License, which permits unrestricted use, distribution, and reproduction in any medium, provided the original work is properly cited.}

Published by Madridge Publishers

\begin{abstract}
The effect of the low temperature short time (LTST) phenomenon on the retention of quality attributes in the peach was tested. Hot water at various temperatures (i.e., control, $30^{\circ} \mathrm{C}, 40^{\circ} \mathrm{C}$ and $50^{\circ} \mathrm{C}$ ) were used as an immersing medium, in which fruits were dipped for 5 minutes. The treated fruits were dried with a dryer and stored for $0,10,20$ and 30 days at room temperature $\left(22^{\circ} \mathrm{C}\right)$ and $70 \%$ humidity, before testing for various quality attributes. The results revealed that fruits immersed in hot water at $40^{\circ} \mathrm{C}$ for $5 \mathrm{~min}$ and stored for 30 days, had significantly lowered the weight loss, titratable acidity and disease incidence as compared to the control fruits. Furthermore, the $\mathrm{pH}$, fruit firmness, TSS and total sugar were comparable to that of control fruits. On an overall basis, the peach fruits performed very well when treated with hot water at $40^{\circ} \mathrm{C}$ and stored for 10 days.
\end{abstract}

Keywords: Peach fruit; Hot water treatment; Storage duration; Quality attributes.

\section{Introduction}

Peach (Prunus persica L.) is an important fruit due to its delicious taste with radically distinctive flavor and nutritive value. Peach is one of the most popular fruit across the globe, which was basically originated from China. According to FAO [1], it is estimated that peach fruit covers 14700 ha of the total cultivated area in Pakistan with an annual production of 55800 tones. The peach fruit is characterized by high perish ability due to its rapid loss of firmness during ripening, yet one of the important stone fruits in Pakistan. The rapid loss of fruit firmness actually favors spoilage of the fruits by microorganisms [2]. Also, the losses in fruit firmness might lead to various physiological disorders that drastically restricts its storage potential and marketing [3]. Keeping in view the importance of peach fruits, a best possible way of fruit storage should be explored to preserve the fruit for sometime (i.e. from the field to the consumer).The Storage time of the peach fruits can be increased by treating the peach fruit with certain sanitizer, oxygen or carbon dioxide, Zinc and Boron or Calcium chloride [2,4-7]. Beside this, peach fruit treated with radiation, hot water or water having electrolytes has the ability to resist incidence of various diseases and fruit decay [3,8-10]. Though, heat is a type of a biotic stresses [11], but the adaptive responses developed by the fruit against such stress can enable them to resist other biotic or a biotic stresses [12]. The most common postharvest heat treatments applied to fruits are hot water, hot water vapor, and hot air to destabilize the 
enzyme systems that can lead to the deterioration of fruits [13-16]. But the improper hot water treatment can lead to the development of high amounts of sugar contents in the fruits [17]. So keeping in view the merits and demerits of hot water treatment on fruit quality, the present study was designed to find the optimum heat treatment of hot water on peach storage.

\section{Materials and Methods}

The experiments on the role of low temperature and short time (LTST) hot water immersion on the quality attributes of peach (Prunus persica) during storage were carried out at Post-harvest lab., The University of Agriculture Peshawar, during the June of 2015 . The peach fruits were harvested at their physiological maturity and only healthy, mature and uniform size fruits were selected, where as the infected and bruised ones were discarded. The experiments were designed according to the completely randomized design (CRD) with two factors, i.e. hot water treatment and storage duration. The fruits were initially immersed in distilled water to remove the impurities and then divided into four lots. One lot was treated as a control, while other lots were treated correspondingly with hot water, i.e. 30,40 and $50^{\circ} \mathrm{C}$ for five minutes. The fruits were then stored at room temperature $\left(22-26^{\circ} \mathrm{C}\right)$ with the relative humidity of $70-75 \%$ for various time intervals (i.e. 0 , 10, 20 and 30 days). The data for different physicochemical attributes were finally recorded at each time interval.

\section{Weight loss (\%)}

After harvesting fresh $(x)$ and after storage $(y)$, the loss in fruit's weight (\%) was determined by using electronic weight meter and the final weight was computed as:

$$
\text { Weight loss }(\%)=\frac{(x-y)}{x} \times 100
$$

\section{Fruit pH}

Peach samples were analyzed for $\mathrm{pH}$ with the help of an Ino lab digital pH meter by a well-defined method of AOAC [18].

\section{TSS ('Brix)}

Total soluble solids (TSS) of the samples were determined by using a digital refractometer (Kernco, Instruments Co. Texas) [18].

\section{Fruit firmness}

A Penetrometer (Effigi, $11 \mathrm{~mm}$ Prob.) assay was used to test the fruits for firmness [18].

\section{Titratable Acidity}

A sample was blended properly, $10 \mathrm{~mL}$ out of it was taken and diluted to $150 \mathrm{~mL}$ with distil water. $A 10 \mathrm{~mL}$ of the diluted sample was transferred to a conical flask and added a few drops of phenolphthalein as an indicator. The contents of the flask were titrated against $0.1 \mathrm{~N} \mathrm{NaOH}$ solution till the development of light pink colour [18]. Titration reading was recorded and percent acidity was calculated by using a formula:

$$
\% \text { Acidity }=\frac{C F \times N \times T \times D \times 100}{V \times S}
$$

Where, $\mathrm{T}=\mathrm{ml}$ of $\mathrm{NaOH}$ used, $\mathrm{D}=$ Dilution Factor, $\mathrm{CF}=$ Correction Factor for peach i.e. 0.067, $\mathrm{N}=$ Normality of $\mathrm{NaOH}, \mathrm{V}=$ Volume of the sample before dilution, $\mathrm{S}=$ Volume of the sample after dilution

\section{Disease incidence (\%)}

The percent disease incidence of peach was visually analyzed every day for each interval and was recorded with the help of following formula:

$$
\text { Disease incidence }(\%)=\frac{\text { infected fruits }}{\text { total fruits }} \times 100
$$

Disease incidence $(\%)=($ infected fruits $) /($ total fruits $) \times 100$

\section{Total sugar (\%)}

The total sugar of a peach (reducing and non-reducing sugar) were examined by the method prescribed in $A O A C$, (1990)

\section{Statistical analysis}

The experiments were designed according to the completely randomized design (CRD) with two factors, using four treatment sin triplicate. The statistical software, "Statistix 8.1" was used for computing both ANOVA and LSD.

\section{Results}

\section{Weight loss (\%)}

The weight losses (\%) of peach fruit during storage were restricted in fruits treated with hot water (i.e. $30^{\circ} \mathrm{C}, 40^{\circ} \mathrm{C}$ and $50^{\circ} \mathrm{C}$ ) as compared to the control (Figure 1). Among the treatment, fruits dipped in hot water at $40^{\circ} \mathrm{C}$ have lost less weight compared to the other treated fruits during the various storage intervals. The data regarding the storage duration revealed that maximum weight loss occurred during the storage interval of 30 days followed by 20 days and 10 days compared to the fresh one. Result showed that the hot water treatment at $40^{\circ} \mathrm{C}$ for 5 minutes was found the best suitable treatment compared to the other treatments for peach fruits during storage.

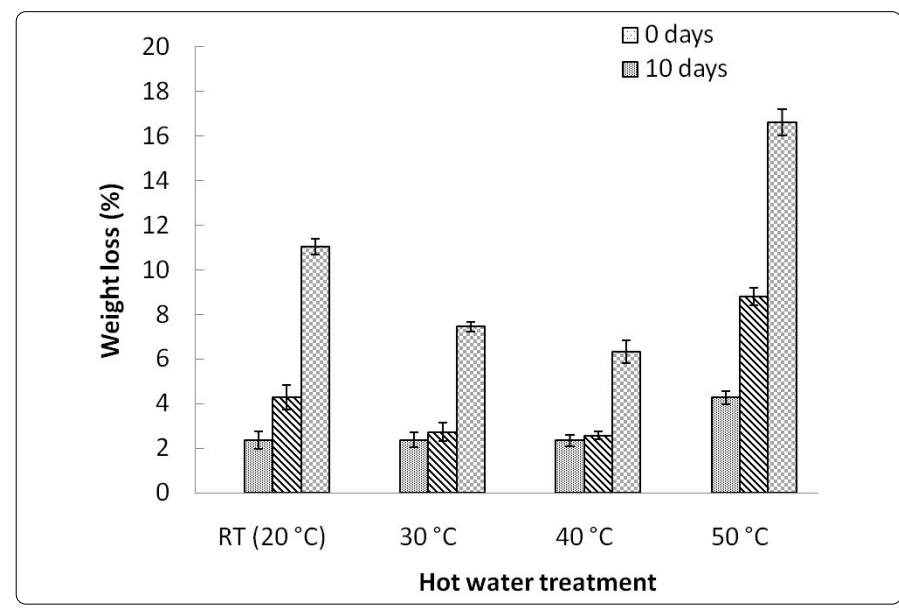

Figure 1. Effect of hot water treatment on weight loss of peach fruit during storage.

The bars represent \pm SE of a triplicate data. 


\section{Fruit firmness}

On a general basis, the firmness of the peach fruits decreased sharply with time in all tested treatments (Figure 2). The fruit firmness for example, in the control treatment was decreased from $2.06 \mathrm{Kg} / \mathrm{cm}^{2}$ to $0.4 \mathrm{Kg} / \mathrm{cm}^{2}$, whereas the firmness of the fruits, submerged in $50^{\circ} \mathrm{C}$ water was declined from $2.03 \mathrm{Kg} / \mathrm{cm}^{2}$ to $0.50 \mathrm{Kg} / \mathrm{cm}^{2}$ during 30 days storage. Similarly, the data observed for fruit firmness showed a significant difference in relation to the hot water treatment. The fruits were found significantly firm when dipped in water retaining $40^{\circ} \mathrm{C}$ temperature and stored for 10 or 20 days compared to the other treatments.

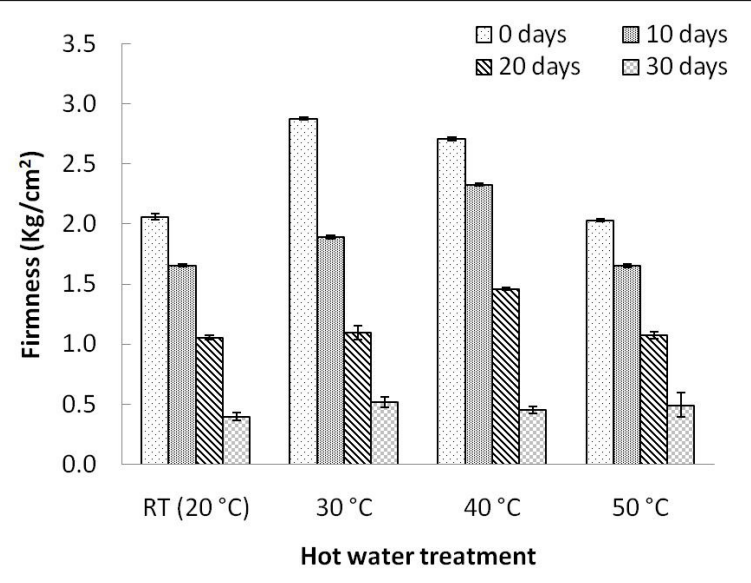

Figure 2. Effect of hot water treatment on peach fruit firmness during storage.

The bars represent \pm SE of a triplicate data.

\section{Total soluble solids ( ${ }^{0}$ Brix)}

The change in total soluble solids (TSS) for various treated fruits during storage is given in figure 3 . The results of our study on peach fruits have shown a slight increase in TSS of all treatments during storage at room temperature. Among the hot water treated fruits, maximum TSS was recorded when the fruits were immersed in a hot water of $50^{\circ} \mathrm{C}$. A comparatively low TTS were observed in fruits treated with water at $40^{\circ} \mathrm{C}$, whereas much lower values were noticed in control fruits and fruits dipped in water holding $30^{\circ} \mathrm{C}$ (Figure 3).

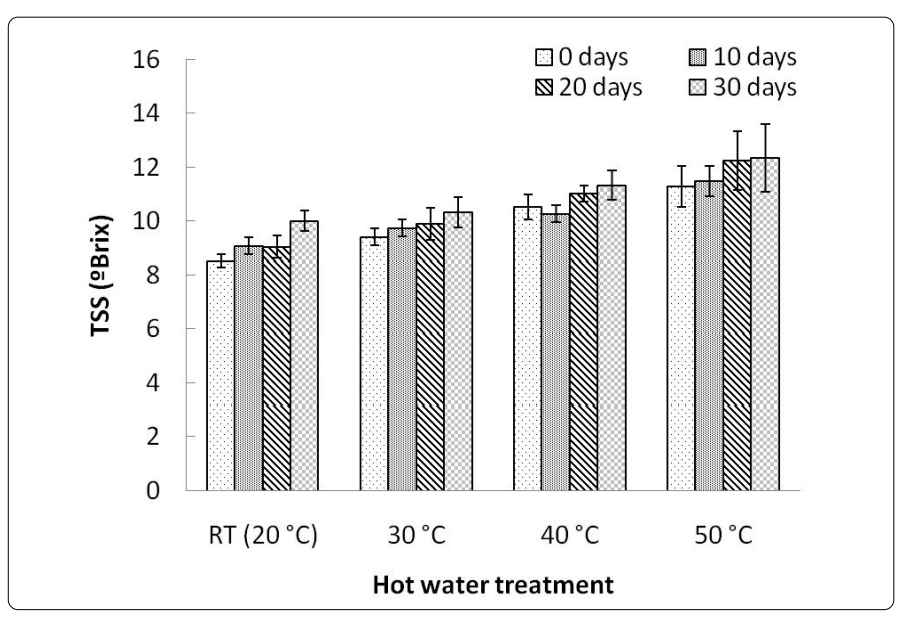

Figure 3. Effect of hot water treatment on TSS of peach fruit during storage

The bars represent \pm SE of a triplicate data.

\section{Total Sugar (\%)}

The results of our experiment showed that the accumulation of the sugar in fruits treated with hot water at $40^{\circ} \mathrm{C}$ and $50^{\circ} \mathrm{C}$ was significantly higher compared to the control fruits (Figure 4). Certainly, the accumulation of the sugar in the above mentioned treatments were very quick that remained almost constant throughout the storage duration. But, the analysis of the fruits on the 30th day of the storage demonstrated significantly different values for the fruits treated with hot water at $50^{\circ} \mathrm{C}$ compared to the other treatments.

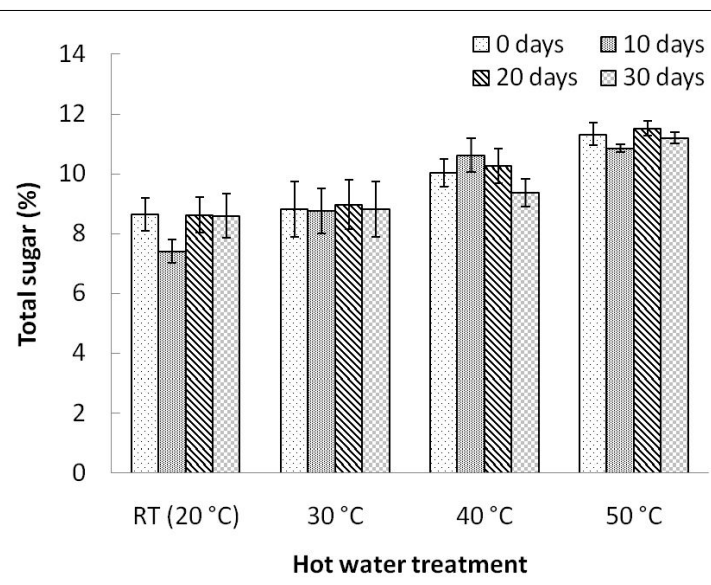

Figure 4. Effect of hot water treatment on sugars of peach fruit during storage.

The bars represent \pm SE of a triplicate data.

\section{Fruit pH}

Fresh peach fruits $\mathrm{pH}$ of both treated and control fruits was significantly increased over time (Figure 5). A maximum increase in $\mathrm{pH}$ was recorded for fruits that were immersed in a hot water solution having a temperature of $50{ }^{\circ} \mathrm{C}$. While comparatively low $\mathrm{pH}$ of the fruits was observed, when immersed in hot water having $40^{\circ} \mathrm{C}$ and $30^{\circ} \mathrm{C}$. A minimum $\mathrm{pH}$ was noted in untreated/control fruits. Considering storage duration, the fruits that were stored for 30 days have significantly high $\mathrm{pH}$, which means that fruit $\mathrm{pH}$ increased throughout the storage period.

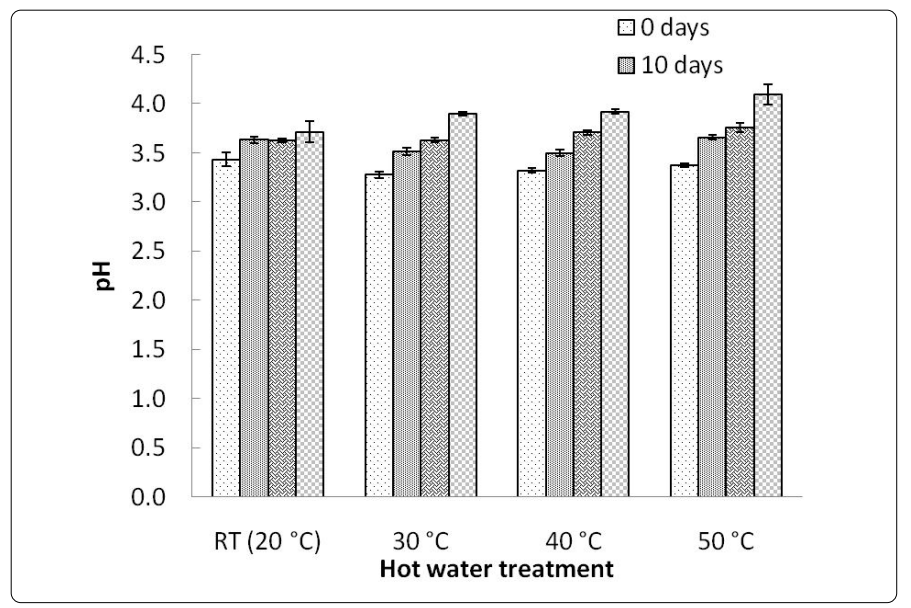

Figure 5. Effect of hot water treatment on $\mathrm{pH}$ of peach fruit during storage.

The bars represent \pm SE of a triplicate data. 


\section{Titratable Acidity}

A maximum titratable acidity $(0.45 \%)$ was recorded in fresh fruit (Control) compared to the other treatments (Figure 6).Though, minimum titratable acidity was recorded when fruits were immersed in $50^{\circ} \mathrm{C}$ hot water solution. The data about the storage effect on the acidity of the fruits revealed a slight change in fruits from all treatments that were tested at various time points. Also, it has been observed that storage of fruits after treating with $30-40{ }^{\circ} \mathrm{C}$ for $10-20$ days don't have a significant effect on the acidity during this period.

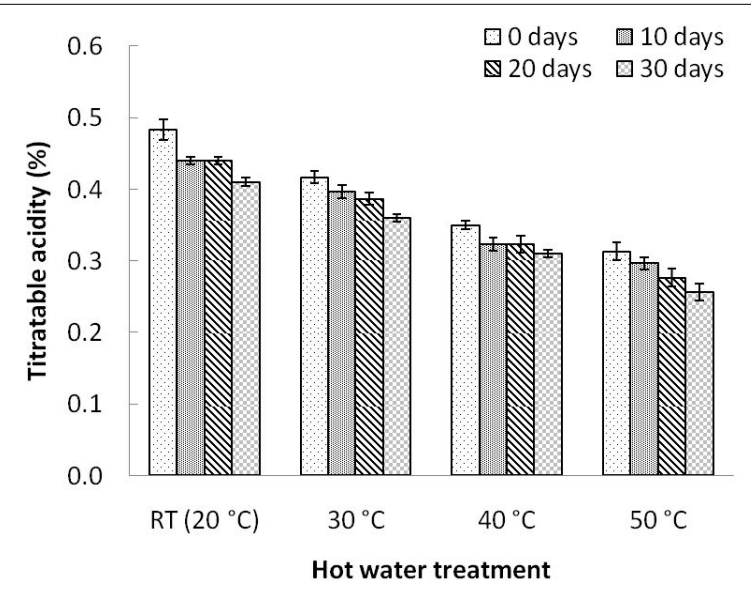

Figure 6. Effect of hot water treatment on titratable acidity of peach fruit during storage.

The bars represent \pm SE of a triplicate data.

\section{Disease incidence (\%)}

Results indicated that the incidence of disease in peach fruits was decreased significantly, when treated with hot water having $30^{\circ} \mathrm{C}$ or $40^{\circ} \mathrm{C}$ compared to the control fruits (Figure 7 ). However, the disease incidence was very high when the fruits were immersed in water at $50^{\circ} \mathrm{C}$ and stored for 30 days. The fruits that were submerged in water at $40^{\circ} \mathrm{C}$ for $5 \mathrm{~min}$ had performed very well during storage and had a significantly lower number of deteriorated fruits.

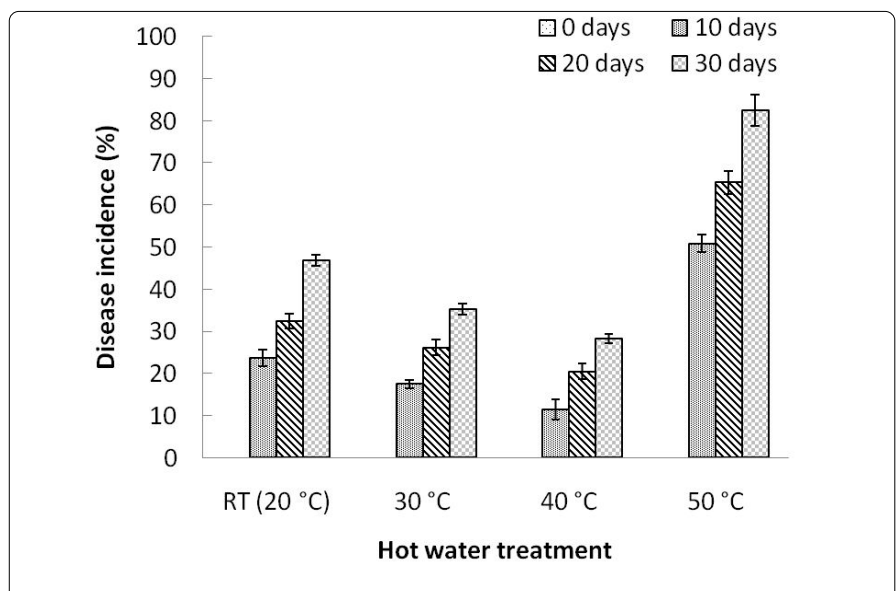

Figure 7. Effect of hot water treatment on diseases incidence of peach fruit during storage.

The bars represent \pm SE of a triplicate data.

\section{Discussion}

Certainly, it is natural for a biological sample to lose moisture content after postharvest. But, it can be controlled by manipulating the conditions before or during the postharvest storage. Though, it was a challenging job to cut down moisture losses in peach fruits during storage, yet not impossible. In this research the higher moisture losses in untreated fruits were controlled by fruits treated with $40^{\circ} \mathrm{C}$ hot water. This effect might be due to the active movement of the water in very small pores at the surface of the fruits (barely observable) and occupying the space. Whereas, hot water treatment at low temperatures will not be able to move up the pores/cracks and occupy the vacant spaces. On the contrary, hot water treatment at high temperatures can open the cracks further that can cause high weight losses through open surfaces. Angasu et al [19], has mentioned in his research that weight losses in dates were lowered by treating the fruits with hot water and stored at ambient temperature. However, Ozdemir et al. [20], and Sajid et al. [6], reported that weight losses of orange fruits during prolonged storage were high by heat treatments. This means that each species of fruit need an optimum time $\times$ temperature combination to restrict losses in moisture effectively.

Fruit firmness is one of the important quality parameters that attract consumers. Fruit firmness is actually connected with the enzymes that are related to the cell wall of the cells (mainly poly-galacturonase) [21]. The enzyme system has the ability to cut the polymers and thus making the tissues after compared to the previously intact one. Heat treatment can de-activate the hydrolytic enzymes that are responsible for softening of fruits. In our study, we have observed a significant loss in fruit firmness in fruits that were treated at $50^{\circ} \mathrm{C}$ for 5 min. A possible explanation for this might be the effect of higher temperatures on membrane integrity. Once, the heat disrupts the cell structure the fruits get soften easily, which has been observed in dragon fruits in the past [22].

The TSS represents the Brix, which normally increases when the fruit loss water during storage. Another valid explanation for that is the conversion of polysaccharides to smaller sugar molecules by their respective enzymes. Both TSS and total sugars of peach fruits in our study, however, didn't effect significantly (both control and hot water treated) during storage. Similar observation has also been reported in strawberries and mangoes in the past by few researchers [19] [23]. The main reason behind such episode might be the low soluble starches in the tested cultivar of peach.

Peach fruit $\mathrm{pH}$ was significantly increased during the storage of the fruits for 30 days in all tested treatments. The high $\mathrm{pH}$ value reflects on the utilization of organic acid into their respective metabolites. On the other hand, titratable acidity decreased as a function of storage time in all tested fruits. The decrease in the acidity is often used as an indicator for maturity as organic acids (i.e. citric acid, malic acid and acetic acid) decrease during the ripening of fruit $[24,25]$. Ghafir et al. [26], also described the dependence of titratable acidity of fruits on their metabolic rate. 
Fruit decay is one of the major causes that limit the shelf life of highly vulnerable fruits [27-29] thus affecting the economic condition of the farmers worldwide. In the modern world the effective management of such losses through potent chemicals is not easy. Strict legislations regarding public safety have pushed the researchers to find alternate ways to tackle the problem. Dipping fruits in hot water might be one of the potential methods to be explored. In our results, we have found that peach fruits treated with hot water at $40^{\circ} \mathrm{C}$ have significantly restricted the decay incidences in the treated fruits during storage for 30 days. Though, the effect of hot water at $50^{\circ} \mathrm{C}$ has increased the chances of incidence by 2-time as compared to the control. The rationale for this might be the hot water effect on the cracks present on the fruit's skin. Upon dipping the fruit in hot water, can wash away the microorganisms initially, but can also open the cracks for future attack.

\section{Conclusion}

In the present research, we have evaluated the effect of hot water on the quality attributes of the peach fruits. From the results it is concluded that the hot water has significantly affected the various quality attributes during storage. The fruits had a low disease incidence, low weight loss and were firm enough to full fill the consumer demands, when treated with hot water at $40^{\circ} \mathrm{C}$. Furthermore, fruits treated with hot water having $40^{\circ} \mathrm{C}$ and stored for 10 days have shown the best results regarding the tested attributes. On the overall basis, we came to the conclusion that if we increase either the application of hot water $\left(\geq 50^{\circ} \mathrm{C}\right.$ for $\geq 5 \mathrm{~min}$ ) or storage duration (i.e. longer than 10 days) for the tested peaches, the incidence of disease and weight loss will occur at a very fast rate.

\section{Conflicts of Interest}

The authors confirm that there is no conflicts of interest regarding this manuscript.

\section{References}

1. FAOSTAT F. Disponível em:<http://faostat. fao. org/site/567/default. aspx\# ancor>. Acessado em setembro. 2010.

2. Jan I, Rab A, Sajid M. Influence of calcium chloride on storability and quality of apple fruits. Pak J Agric Sci. 2015; 52(1): 115-122.

3. Mahajan PV, Caleb O, Singh Z, Watkins C, Geyer M. Postharvest treatments of fresh produce. Philos Trans A Math Phys Eng Sci. 2014; 372(2017): 1-19. doi: 10.1098/rsta.2013.0309

4. Tan SY, Mikš-Krajnik M, Neo SY, Tan A, Khoo GH, Yuk HG. Effectiveness of various sanitizer treatments for inactivating natural microflora and Salmonella spp. on turnip (Pachyrhizus erosus). Food Control. 2015; 54: 216-224.

5. Ullah H, Ahmad S, Anwar R, Nafees M, Thompson A. Effect of'oxygen and carbon-dioxide'on the post-harvest management in tree-ripe mango storage. J Chem Soc Pak. 2010; 32(4): 485-491.

6. Sajid M, Jan I, Shah ST, Iqbal A, Zamin M, Shakur M. Pre-harvest treatment of $\mathrm{Zn} \& \mathrm{~B}$ affects the fruit quality and storability of sweet orange. J Agric Sci Technol. 2012; 2(12B): 1224-1233.
7. Sajid M, Mukhtiar M, Rab A, Shah ST, Jan I. Influence of Calcium Chloride $(\mathrm{CaCl} 2)$ on fruit quality of pear (Pyrus communis) cv. le conte during storage. Pak J Agric Sci. 2014; 51(1): 113-121.

8. Hung YC, Tilly P, Kim C. Efficacy of electrolyzed oxidizing (EO) water and chlorinated water for inactivation of Escherichia coli $0157: \mathrm{H} 7$ on strawberries and broccoli. J Food Qual. 2010; 33(5): 559-577. doi: 10.1111/j.1745-4557.2010.00344.x

9. Issa-Zacharia A, Kamitani Y, Miwa N, Muhimbula H, Iwasaki K. Application of slightly acidic electrolyzed water as a potential non-thermal food sanitizer for decontamination of fresh ready-to-eat vegetables and sprouts. Food Control. 2011; 22(3): 601-607. doi: 10.1016/j. foodcont.2010.10.011

10. Rahman $\mathrm{S}$, Ding $\mathrm{T}$, Oh $\mathrm{D}-\mathrm{H}$. Effectiveness of low concentration electrolyzed water to inactivate foodborne pathogens under different environmental conditions. Int J Food Microbiol. 2010; 139(3): 147-153. doi: 10.1016/j.ijfoodmicro.2010.03.020

11. Lata $C$, Prasad M. Role of DREBs in regulation of abiotic stress responses in plants. J Exp Bot. 2011; 62(14): 4731-4748. doi: 10.1093/jxb/err210

12. Hasanuzzaman $M$, Nahar $K$, Alam MM, Roychowdhury R, Fujita M. Physiological, biochemical, and molecular mechanisms of heat stress tolerance in plants. Int J Mol Sci. 2013; 14(5): 9643-9684. doi: 10.3390/ ijms14059643

13. Mirdehghan $S$, Rahemi $M$, Martínez-Romero $D$, et al. Reduction of pomegranate chilling injury during storage after heat treatment: role of polyamines. Postharvest Biol Technol. 2007; 44(1): 19-25. doi: 10.1016/j. postharvbio.2006.11.001

14. Hong S-I, Lee $\mathrm{H}-\mathrm{H}$, Kim D. Effects of hot water treatment on the storage stability of satsuma mandarin as a postharvest decay control. Postharvest Biol Technol. 2007; 43(2):271-279. doi: 10.1016/j.postharvbio.2006.09.008

15. Kim Y, Brecht JK, Talcott ST. Antioxidant phytochemical and fruit quality changes in mango (Mangifera indica L.) following hot water immersion and controlled atmosphere storage. Food Chem. 2007; 105(4): 13271334. doi: 10.1016/j.foodchem.2007.03.050

16. Zhang $H$, Wang $L$, Zheng $X$, Dong $Y$. Effect of yeast antagonist in combination with heat treatment on postharvest blue mold decay and Rhizopus decay of peaches. Int J Food Microbiol. 2007; 115(1): 53-58. doi: 10.1016/j.jijfoodmicro.2006.10.002

17. Ansari NA, Feridoon H. Postharvest application of hot water, fungicide and waxing on the shelf life of valencia and local oranges of siavarz. Asian J Plant Sci. 2007; 6(2): 314-319. doi: 10.3923/ajps.2007.314.319

18. AOAC. Official methods of analysis. 19th ed. Gaithersburg, Maryland, USA 2012

19. Angasu ON, Dessalgne OG, Tadesse TN. Effect of hot water treatment on quality and incidence of postharvest disease of mango (Mangifera indicia L.) fruits. Asian J Plant Sci. 2014; 13(2): 87. doi: 10.3923/ ajps.2014.87.92

20. Ozdemir A, Dundar O. The effects of fungicide and hot water treatments on the internal quality parameters of Valencia oranges. Asian J Plant Sci. 2006; 5(1): 142-146. doi: 10.3923/ajps.2006.142.146

21. Zhou R, Li Y, Yan L, Xie J. Effect of edible coatings on enzymes, cellmembrane integrity, and cell-wall constituents in relation to brittleness and firmness of Huanghua pears (Pyrus pyrifolia Nakai, cv. Huanghua) during storage. Food Chem. 2011; 124(2): 569-575. doi: 10.1016/j. foodchem.2010.06.075

22. Lum MS, Norazira M. Effects of hot water, submergence time and storage duration on quality of dragon fruit (Hylocereus polyrhizus). J Agric Sci. 2011; 3(1):146-152. doi: 10.5539/jas.v3n1p146

23. Shafiee M, Taghavi T, Babalar M. Addition of salicylic acid to nutrient solution combined with postharvest treatments (hot water, salicylic acid and calcium dipping) improved postharvest fruit quality of strawberry. Sci Hort. 2010; 124(1): 40-45. doi: 10.1016/j.scienta.2009.12.004

24. Workneh TS, Osthoff G, Steyn M. Effects of preharvest treatment disinfections, packaging and storage environment on quality of tomato. $J$ Food Sci Technol. 2012; 49(6): 685-694. doi: 10.1007/s13197-011-0391-3 
25. Kassem H, El-Kobbia AM, Marzouk HA, El-Sebaiey MM. Effect of foliar sprays on fruit retention, quality and yield of Costata persimmon trees. Emirates J Food Agric. 2010; 22(4): 259-274. doi: 10.9755/ejfa.v22i4.5222

26. Ghafir SA, Gadalla SO, Murajei BN, El-Nady MF. Physiological and anatomical comparison between four different apple cultivars under cold-storage conditions. Afr J Plant Sci. 2009; 3(6): 133-138.

27. Ghasemnezhad M, Marsh K, Shilton R, Babalar M, Woolf A. Effect of hot water treatments on chilling injury and heat damage in 'satsuma'mandarins: Antioxidant enzymes and vacuolar ATPase, and pyrophosphatase. Postharvest Biol Technol. 2008; 48(3): 364-371. doi: 10.1016/j.postharvbio.2007.09.014
28. Liu J, Sui Y, Wisniewski M, et al. Effect of heat treatment on inhibition of Monilinia fructicola and induction of disease resistance in peach fruit. Postharvest Biol Technol. 2012; 65: 61-68. doi: 10.1016/j. postharvbio.2011.11.002

29. Yuan L, Bi Y, Ge Y, Wang Y, Liu Y, Li G. Postharvest hot water dipping reduces decay by inducing disease resistance and maintaining firmness in muskmelon (Cucumis melo L.) fruit. Sci Hort. 2013; 161: 101-110. doi: 10.1016/j.scienta.2013.06.041 